\title{
Karyological, biochemical, and physiological aspects of Callophysus macropterus (Siluriformes, Pimelodidae) from the Solimões and Negro Rivers (Central Amazon)
}

H. Ramirez-Gil, E. Feldberg²,

V.M.F. Almeida-Val ${ }^{2}$ and A.L. Val ${ }^{2}$
${ }^{1}$ Instituto N acional de Pesca y Acuicultura, IN PA, Puerto López, Meta, Colombia 2Instituto Nacional de Pesquisas da Amazônia, Manaus, AM, Brasil

\section{Correspondence}

A.L. Val

Instituto Nacional de Pesquisas da Amazônia, INPA

Alameda Cosme Ferreira, 1756

69083-000 Manaus, AM

Brasil

Research supported by CN Pq. A.L. Val and V.M.F. Almeida-Val are recipients of $\mathrm{CNPq}$ fellowships.

Received April 14, 1998 Accepted August 17, 1998

\section{Abstract}

Karyological characteristics, i.e., diploid number, chromosome morphology and nucleolus organizer regions (NORs), biochemical characteristics, i.e., electrophoretic analysis of blood hemoglobin and the tissue enzymes lactate dehydrogenase (LDH), malate dehydrogenase (MDH), alcohol dehydrogenase (ADH), and phosphoglucose isomerase (PGI), and physiological characteristics, i.e., relative concentration of hemoglobin and intraerythrocytic concentrations of organic phosphates were analyzed for the species Callophysus macropterus collected from Marchantaria Island (white water system - Solimões River) and Anavilhanas Archipelago (black water system - Negro River). Karyological and biochemical data did not reveal significant differences between specimens collected at the two sites. However, the relative distribution of hemoglobin bands I and III ( $\mathrm{I}=16.33 \pm 1.05$ and $\mathrm{III}=37.20 \pm 1.32$ for Marchantaria specimens and $\mathrm{I}=6.33 \pm 1.32$ and III $=48.05 \pm 1.55$ for Anavilhanas specimens) and levels of intraerythrocytic GTP $(1.32 \pm 0.16$ and $2.76 \pm 0.18$ for Marchantaria and Anavilhanas specimens, respectively), but not ATP or total phosphate, were significantly different, indicating a physiological adaptation to the environmental conditions of these habitats. It is suggested that $C$. macropterus specimens from the two collecting sites belong to a single population, and that they adjusted some physiological characteristics to adapt to local environmental conditions.

\section{Introduction}

The Amazon region presents a wide variety of aquatic environments separated by geographical barriers that limit gene flow among individuals. Although it has been postulated that this has produced a high intraspecific heterogeneity in fish populations,
Key words

- Callophysus

- Fish

- Amazon

- Population genetics

- Adaptation few studies have been conducted on this topic. Not only do different environments present adaptive challenges, but also any single environment can have wide fluctuations that additionally challenge its inhabitants. The capacity of organisms to adapt to such unstable environments may be linked to genetic and biological variability. However, 
physiological plasticity at the individual level also permits exploitation of different environments. Presently, little is known about environmental effects on the distribution and abundance of populations versus biochemical and physiological variability.

The species of fish chosen for this study belongs to the family Pimelodidae, genus Callophysus, which is monotypic. Callophysus macropterus, locally known as "piracatinga", is found dispersed across the Amazon basin and in the Orinoco River, being commercially exploited in both systems. Callophysus macropterus is representative of a migratory species of catfish (Siluriformes) and is abundant in a wide variety of environments. Thus, it is a convenient subject for studies of population structure and adaptive responses to different environmental conditions.

Karyotype and structural and functional properties of isozymes, allozymes, and hemoglobin among other proteins have been helpful for the evaluation of evolutionary aspects and population structures of fishes (1-6). In addition, it is believed that an examination of the physiology of hemoglobinoxygen affinity and its allosteric modulators, the intraerythrocytic phosphates, is important to characterize the adaptive capacity of fish populations (7). Thus, the application of cytogenetic, biochemical, and physiological methods to assess population differences provides an objective approach to probing responses to environmental heterogeneity. The present study uses these tools to examine differences and similarities in C. $\mathrm{ma}$ cropterus in order to assess how this species has responded to two different environments. Is this ability to exploit two environments due to genetic-biochemical differences or to a physiological adaptive response?

\section{Material and Methods}

Callophysus macropterus specimens were obtained from the Solimões River, near
Marchantaria Island $\left(60^{\circ} 00^{\prime} \mathrm{W} 3^{\circ} 15^{\prime} \mathrm{S}\right)$, and from the Anavilhanas Archipelago, Negro River $\left(60^{\circ} 45^{\prime} \mathrm{W} 2^{\circ} 43^{\prime} \mathrm{S}\right)$, during the lowwater season.

\section{Chromosome analyses}

Forty live specimens from Marchantaria Island and 15 from the Anavilhanas Archipelago were studied. Chromosome preparations were obtained from kidney cell suspensions by the air-drying method of Bertollo and co-workers (8), which was modified by using $0.025 \%$ colchicine and an exposure time of 45-90 min. The nucleolus organizer regions (NORs) were identified by silver staining according to the technique of Howell and Black (9). Chromosome morphology was determined on the basis of arm ratios, as recommended by Levan and co-workers (10).

\section{Isozyme analyses}

Samples of skeletal muscle, liver, heart, eye, and brain were routinely obtained from the fish (110 Marchantaria Island specimens and 43 Anavilhanas Archipelago specimens), kept first in an ice-salt mixture $\left(-17^{\circ} \mathrm{C}\right)$ during transport to the laboratory and then stored at $-20^{\circ} \mathrm{C}$ until the time for analysis. Samples were homogenized for $10 \mathrm{~s}$ at $4^{\circ} \mathrm{C}$ using a Sorvall Omnimixer in phosphate buffer, $\mathrm{pH}$ $7.0(1 / 1, \mathrm{w} / \mathrm{v})$, and centrifuged at $27,000 \mathrm{~g}$ for $30 \mathrm{~min}$ at $4^{\circ} \mathrm{C}$ in a refrigerated centrifuge. The supernatants were used for electrophoresis.

Horizontal starch gels were prepared $(13 \%, w / v)$ according to Val and co-workers (11). For lactate dehydrogenase (LDH, E.C. 1.1.1.27), phosphoglucose isomerase (PGI, E.C. 5.3.1.9), and alcohol dehydrogenase (ADH, A.C. 1.1.1.1) the buffer system was prepared according to Boyer and co-workers (12). For malate dehydrogenase (MDH, E.C. 1.1.1.27) the buffer system was Tris-citrate (13). Electrophoresis was carried out for 14 
h at $4^{\circ} \mathrm{C}$ by applying $6 \mathrm{~V} / \mathrm{cm}$ with a Pharmacia EPS 500/400 power supply.

Gels were stained according to procedures outlined by Shaklee and co-workers (14) for LDH, by Shaw and Prassad (15) for $\mathrm{MDH}$, by DeLorenzo and Ruddle (16) for PGI, and by Brewer (17) for ADH. The nomenclature specified for alleles at each locus is according to the International Biochemical Commission.

To test the observed genotypic distributions against the expected Hardy-Weinberg distribution, a G-test (18) was used. A contingency $\chi^{2}$ test (19) was used to determine the significance of inter-sample homogeneity in allele frequencies.

\section{Measurement of hemoglobin}

Blood samples from 30 Marchantaria Island specimens and 21 Anavilhanas Archipelago specimens were collected from the caudal vein into heparinized syringes immediately upon capture and kept on ice until processing. Plasma was removed from blood, and after washing three times with ice-cold saline solution $(0.9 \%)$, the red blood cells (RBC) were lysed with $5 \mathrm{mM}$ Tris- $\mathrm{HCl}, \mathrm{pH}$ 8.0 ( 1 part RBC to 5 parts Tris) and frozen at $-20^{\circ} \mathrm{C}$. The stroma was eliminated by centrifugation at 20,000 $\mathrm{g}$ for $20 \mathrm{~min}$ at $4^{\circ} \mathrm{C}$ in a Sorvall RC-5B refrigerated centrifuge and the hemolysates were stored at $4^{\circ} \mathrm{C}$ and used for electrophoresis.

The electrophoretic patterns of hemoglobin were obtained by starch gel electrophoresis (20), and with agar-starch on microscope slides according to Araújo and coworkers (21), modified by Machado (22) using corn starch $(13 \mathrm{~g} / 100 \mathrm{ml})(11)$. The same buffer system was used for both media: Tris-borate-EDTA (0.9 M Tris, $0.2 \mathrm{M}$ boric acid, and 0.02 M EDTA acid, pH 8.6, diluted $1 / 40$ in water). Borate buffer, $0.35 \mathrm{M}, \mathrm{pH}$ 8.6, for the starch gel and $0.035 \mathrm{M}, \mathrm{pH} 8.6$, for the agar-starch were used in electrode vessels. Electrophoresis was carried out at $4^{\circ} \mathrm{C}$ with a Pharmacia EPS 500/400 power supply.

The starch gels were stained with amido black 10B for total proteins and with benzidine for hemoglobin. The agar-starch-coated slides were stained only with amido black 10B. The relative concentration of each hemoglobin fraction was determined on agarstarch-coated slides using an Argos 7/8 densitometer. The $t$-test was used to determine significant differences between sample hemoglobin concentrations.

\section{Measurement of intraerythrocytic phosphates}

Blood samples of various specimens of C. macropterus were pooled. The plasma was removed and the phosphates were extracted with $0.6 \mathrm{M}$ perchloric acid. The extracts ( $\mathrm{N}=6$ for both collecting sites) were chromatographed using a Dowex $1 \times 8$ resin, 400 mesh, in a $28 \times 1 \mathrm{~cm}$ column according to Bartlett (23). The method described by Bartlett (24) was used to determine if inositol polyphosphate was present.

\section{Results}

\section{Karyotypes and nucleolus organizer regions}

The karyotype of $C$. macropterus obtained at the two sites was characterized by a diploid number of $2 \mathrm{n}=50$ chromosomes, 22 metacentric (pairs 1-11), 18 submetacentric (pairs 12-20) and 10 acrocentric (pairs 2125) chromosomes (Figure 1). The fundamental number was 90 for all specimens analyzed. No significant karyotypic differences were observed between animals from the two collecting sites. A single pair of NOR-bearing chromosomes was detected, coinciding with a secondary constriction located on the short arms of an acrocentric chromosome pair, the 22nd pair in the complement. The NORs were heteromorphic. No differences were observed with 
respect to gender or collection site.

\section{Isozymes}

LDH was monomorphic in all specimens of $C$. macropterus caught at the two sites. The LDH distribution in the tissue suggests that this enzyme is coded by two co-dominant loci (LDH-A* and LDH-B*) that characterize subunits $\mathrm{A}$ and $\mathrm{B}$, respectively. The enzyme is a tetramer and is present as five isozymes $\left(A_{4}, A_{3} B_{1}, A_{2} B_{2}, A_{1} B_{3}, B_{4}\right)$ with typical binomial distribution. As expected, isozyme $\mathrm{A}_{4}$ predominated in skeletal muscle and isozyme $\mathrm{B}_{4}$ predominated in heart muscle (Figure 2).

MDH was present in two forms, the mitochondrial (m-MDH) and the cytosolic or soluble form (s-MDH) (Figure 2). s-MDH was characterized by three anodic bands suggesting a dimeric composition coded by two gene loci: MDH-A* and MDH-B*. These isozymes were tissue specific; in other words, isozyme $\mathrm{A}_{2}$ predominated in the liver and $\mathrm{B}_{2}$ in muscle. $\mathrm{MDH}$, like $\mathrm{LDH}$, revealed a monomorphic pattern in specimens from the two collecting sites.

The ADH enzyme was detected only in the liver (Figure 2) and showed a single cathodic migration band for all samples. The electrophoretic pattern was monomorphic and similar for the individuals from both sites.

The PGI enzyme was characterized by three symmetrically distributed electrophoretic bands, indicating its dimeric composition as expressed by two co-dominant gene loci. Loci PGI-A* and PGI-B* codify the isozymes $\mathrm{A}$ and $\mathrm{B}$, respectively. These isozymes are distributed in the different tissues in the following way: isozyme $A_{2}$ is predominant in liver, eye, and brain and $\mathrm{B}_{2}$
Figure 1 - Karyotype of Callophysus macropterus $(2 \mathrm{n}=50)$ collected from the Solimões River, near Marchantaria Island (top), and from the Negro River, near Anavilhanas Archipelago (bottom). M, Metacentric; SM, submetacentric; A, acrocentric.
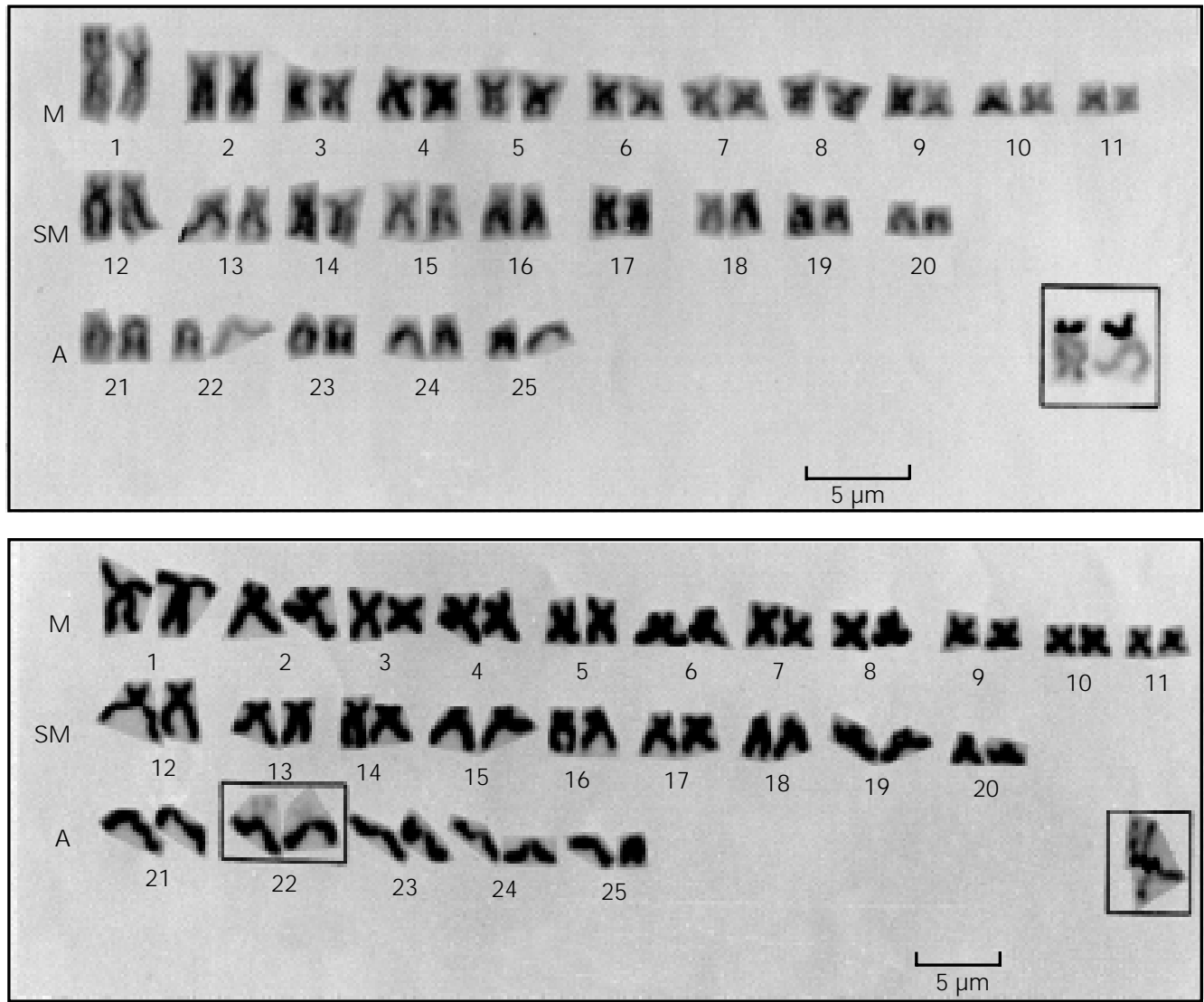
in muscle. The heterodimer $\mathrm{AB}$ appears in the heart, together with a moderate presence of homodimer $\mathrm{A}_{2}$. Four alleles were detected for PGI in the two populations: A-100, A120, B-100, and B-450. All possible patterns were found in the two populations (Figure 3).

Allele analysis showed no significant difference between heterozygotes from the two collecting sites (Table 1). The genotypic distribution was found to be the same for the individuals collected from both sites. The $\chi^{2}$ values were not significant $(\mathrm{P}>0.05)$, also when the data from the two sites were combined.

The contingency test (Table 2) shows the gene frequency of the alleles present in both populations. The genetic composition of the specimens captured from Marchantaria Island site was not significantly different $(\mathrm{P}>0.05)$ from the genetic composition of specimens collected from the Anavilhanas Archipelago.

\section{Hemoglobin electrophoresis}

Starch gel electrophoresis of the hemolysates of $C$. macropterus from the two sites revealed three hemoglobin bands, each band presenting identical electrophoretic mobility for all analyzed specimens. In agar-starch, a variation was observed in the relative concentration of the three bands of hemoglobin. The mean concentration of band I was significantly higher $(t$-test, $\mathrm{P}<0.001)$ in the animals collected from Marchantaria Island. The concentration of band II did not differ significantly between the individuals from the two sites. The mean concentration of band III was significantly higher in the animals from Anavilhanas Archipelago ( $t$-test, $\mathrm{P}<0.001)$. These results are summarized in Figure 4.

\section{Intraerythrocytic phosphates}

No qualitative differences were observed in the chromatographic patterns of intraerythrocytic phosphates between specimens from the two collecting sites. Inositol polyphosphate was not detected in the erythrocytes of $C$. macropterus. The phosphates primarily detected were: ADP, ATP, GTP, and Fe-GTP. There was, however, a quantitative difference in GTP between samples from the two sites (Figure 5). GTP concen-
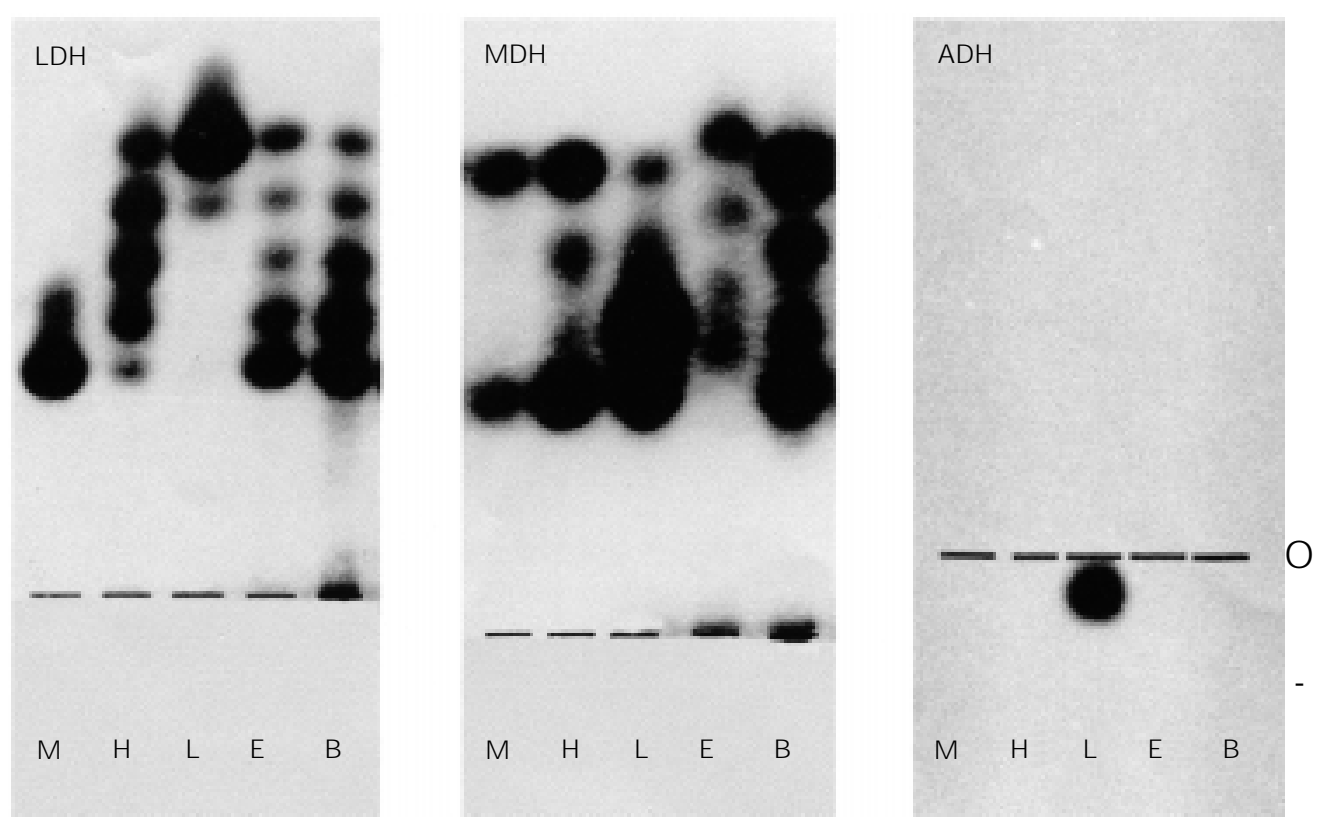

Figure 2 - Distribution of isozymes of lactate dehydrogenase $(\mathrm{LDH})$, malate dehydrogenase (MDH), and alcohol dehydrogenase $(\mathrm{ADH})$ in skeletal muscle $(M)$, heart $(H)$, liver $(L)$, eye $(E)$, and brain (B) of Callophysus macropterus. $\mathrm{O}=$ Origin. 
trations for samples from Anavilhanas Archipelago were significantly higher $(\mathrm{P}<0.05)$ than those for samples from Marchantaria Island. Concentrations of inorganic phosphorus and ATP were not significantly different. ATP and GTP ratios also differed. The ATP/GTP ratio was less than 1 for the individuals from Anavilhanas Archipelago and higher than 1 for the individuals from Marchantaria Island.

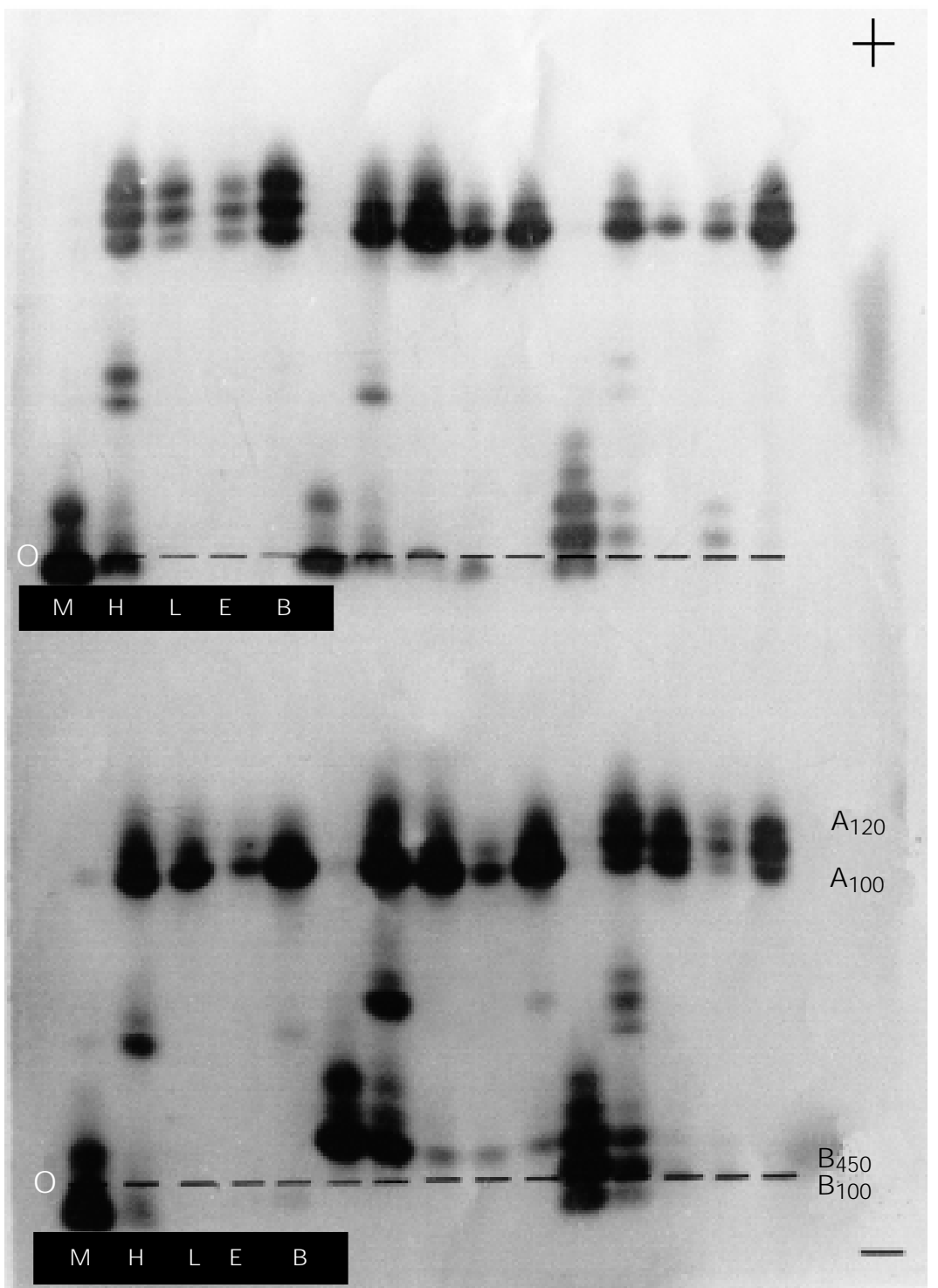

Figure 3 - Distribution of isozymes and allozymes of phosphoglucoisomerase (PGI) in muscle $(M)$, heart $(H)$, liver $(L)$, eye $(E)$, and brain $(B)$ of $C$. macropterus specimens collected from the Solimões River, near Marchantaria Island (top), and from the Negro River, near Anavilhanas Archipelago (bottom). Four allelic forms were found in animals from both sites $\left(A_{100}, A_{120}, B_{100}\right.$, and $\left.B_{450}\right) . O=$ Origin.

\section{Discussion}

Based on karyotypic observations of some fish species of the family Pimelodidae, we may state that populations of the same species having different karyotypes can be found within the same hydrographic basin, as reported for species of Rhamdia $(25,26)$. Such differences have been related to supernumerary chromosomes that may confer adaptive advantages. However, the species studied here, $C$. macropterus, also a member of the Pimelodidae family, exhibits a single karyotype for the animals from both collecting places.

It is important to note here that out of the 258 South American species of the Pimelodidae family, only about 20 had their karyotypes studied. Currently available information indicates that the Pimelodidae family has a diploid chromosome number varying from $2 \mathrm{n}=46$ in Pimelodella sp (27) to $2 \mathrm{n}=$ 63 in Rhamdia hillari (26), with most of the analyzed species having $2 \mathrm{n}=56$ (28).

Most of the pimelodids possess NORs located on the short arm of a single chromosome pair (29). In C. macropterus they were found on the short arms of the 22nd pair of acrocentric chromosomes. The heteromorphism in NOR size found in C. macropterus was closely similar to that found in Pseudoplatystoma fasciatum and $P$. tigrinum, showing a convergent pattern among these species. The NOR heteromorphism in $\mathrm{C}$. $\mathrm{ma}$ cropterus is not associated with the collecting sites. The lack of karyotypic variation suggests a high similarity among animals from the two environments.

A pattern of five LDH isozymes closely similar to that found for C. macropterus has been described for other species of catfish: Pseudoplatystoma tigrinum, Brachyplatystoma filamentosum, Hoplosternum littorale (30), Pimelodus maculatus (31), Ictalurus sp, I. nebulosus, I. marmoratus and I. punctatus (32). There are interspecific differences in LDH electrophoretic mobility 
Table 1 - Test of Hardy Weinberg equilibrium for PGI-A and PGI-B of Callophysus macropterus from Marchantaria Island and Anavilhanas Archipelago.

\begin{tabular}{|c|c|c|c|c|c|c|c|c|}
\hline \multirow[t]{2}{*}{ Site } & \multicolumn{3}{|c|}{ Genotype } & \multicolumn{2}{|c|}{ Allele frequencies } & \multirow[t]{2}{*}{ d.f. } & \multirow[t]{2}{*}{$\chi^{2}$} & \multirow[t]{2}{*}{$\mathrm{P}$} \\
\hline & $A_{100}$ & $A_{100} A_{120}$ & $A_{120}$ & $A_{100}$ & $B_{120}$ & & & \\
\hline Marchantaria & $\begin{array}{l}92 \\
(92.16)\end{array}$ & $\begin{array}{l}8 \\
(7.68)\end{array}$ & $\begin{array}{l}0 \\
(0.16)\end{array}$ & 0.96 & 0.04 & 1 & 0.174 & $0.7-0.5$ \\
\hline Anavilhanas & $\begin{array}{l}35 \\
(34.81)\end{array}$ & $\begin{array}{l}2 \\
(2.15)\end{array}$ & $\begin{array}{l}0 \\
(0.03)\end{array}$ & 0.97 & 0.03 & 1 & 0.04 & $0.95-0.9$ \\
\hline Total & $\begin{array}{l}127 \\
(126.26)\end{array}$ & $\begin{array}{l}10 \\
(10.52)\end{array}$ & $\begin{array}{l}0 \\
(0.22)\end{array}$ & 0.96 & 0.04 & 1 & 0.249 & $0.9-0.8$ \\
\hline $\begin{array}{l}\Sigma \chi^{2} \\
\text { Heterozygosity }\end{array}$ & & & & & & 2 & $\begin{array}{l}0.219 \\
0.030\end{array}$ & $\begin{array}{l}0.9-0.8 \\
0.9-0.8\end{array}$ \\
\hline \multirow[t]{2}{*}{ Site } & \multicolumn{3}{|c|}{ Genotype } & \multicolumn{2}{|c|}{ Allele frequencies } & d.f. & $\chi^{2}$ & $P$ \\
\hline & $B_{100}$ & $\mathrm{~B}_{100} \mathrm{~B}_{450}$ & $B_{450}$ & $B_{100}$ & $B_{450}$ & & & \\
\hline Marchantaria & $\begin{array}{l}37 \\
(37.82)\end{array}$ & $\begin{array}{l}49 \\
(47.35)\end{array}$ & $\begin{array}{l}14 \\
(14.82)\end{array}$ & 0.615 & 0.385 & 1 & 0.120 & $0.8-0.7$ \\
\hline Anavilhanas & $\begin{array}{l}13 \\
(11.89)\end{array}$ & $\begin{array}{l}16 \\
(18.17)\end{array}$ & $\begin{array}{l}8 \\
(6.94)\end{array}$ & 0.567 & 0.433 & 1 & 0.525 & $0.5-0.3$ \\
\hline Total & $\begin{array}{l}50 \\
(49.65)\end{array}$ & $\begin{array}{l}65 \\
(65.65)\end{array}$ & $\begin{array}{l}22 \\
(21.70)\end{array}$ & 0.602 & 0.398 & 1 & 0.013 & $0.95-0.9$ \\
\hline$\Sigma \chi^{2}$ & & & & & & 2 & 0.645 & $0.5-0.3$ \\
\hline Heterozygosity & & & & & & & 0.632 & $0.5-0.3$ \\
\hline
\end{tabular}

Table 2 - Contingency analyses of the homogeneity of PGI-A and PGI-B alleles of Callophysus macropterus from Marchantaria Island and Anavilhanas Archipelago.

\begin{tabular}{|c|c|c|c|c|c|c|c|}
\hline \multirow[t]{2}{*}{ Site } & \multirow[t]{2}{*}{$\mathrm{n}$} & \multicolumn{2}{|c|}{ Genotype } & \multirow[t]{2}{*}{ Allele frequencies } & \multirow[t]{2}{*}{ d.f. } & \multirow[t]{2}{*}{$\chi^{2}$} & \multirow[t]{2}{*}{$P$} \\
\hline & & $A_{100}$ & $A_{120}$ & & & & \\
\hline Marchantaria & $\begin{array}{l}100 \\
(185.40)\end{array}$ & $\begin{array}{l}184 \\
(14.60)\end{array}$ & 16 & 200 & 1 & 0.145 & $0.8-0.7$ \\
\hline Anavilhanas & 37 & $\begin{array}{l}70 \\
(68.60)\end{array}$ & $\begin{array}{l}4 \\
(5.4)\end{array}$ & 74 & 1 & 0.391 & $0.7-0.5$ \\
\hline Total & 137 & 254 & 20 & 274 & 1 & 0.536 & $0.5-0.3$ \\
\hline \multirow[t]{2}{*}{ Site } & $\mathrm{n}$ & \multicolumn{2}{|c|}{ Genotype } & Allele frequencies & d.f. & $\chi^{2}$ & $P$ \\
\hline & & $\mathrm{B}_{100}$ & $B_{450}$ & & & & \\
\hline Marchantaria & $\begin{array}{l}100 \\
(120.44)\end{array}$ & $\begin{array}{l}123 \\
(79.56)\end{array}$ & 77 & 200 & 1 & 0.137 & $0.8-0.7$ \\
\hline Anavilhanas & 37 & $\begin{array}{l}42 \\
(44.56)\end{array}$ & $\begin{array}{l}32 \\
(29.44)\end{array}$ & 74 & 1 & 0.369 & $0.7-0.5$ \\
\hline Total & 137 & 165 & 109 & 274 & 1 & 0.506 & $0.5-0.3$ \\
\hline
\end{tabular}


Figure 4 - Relative concentration (\%) of electrophoretic hemoglobin bands of Callophysus macropterus collected from the Solimões River, near Marchantaria Island (filled columns), and from the Negro River, near Anavilhanas Archipelago (open columns). Asterisks indicate significant differences $(P<0.05)$ between specimens from different collecting sites (t-test).

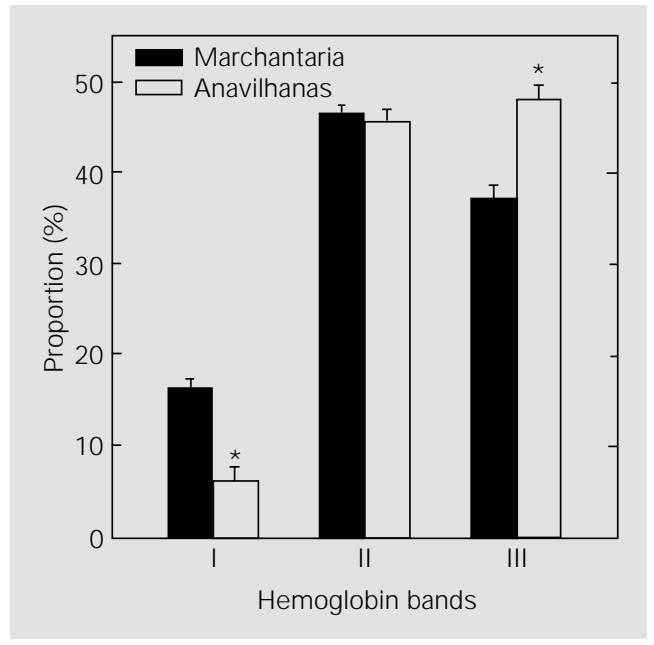

Figure 5 - Inorganic phosphate $(\mathrm{Pi})$, adenosine triphosphate (ATP) and guanosine triphos phate (GTP) in red blood cells of Callophysus macropterus collected from the Solimões River, near Marchantaria Island (filled columns), and from the Negro River, near Anavilhanas Archipelago (open columns). Asterisk indicates significant differences $(P<0.05)$ between specimens from different collecting sites ( $t$ test).

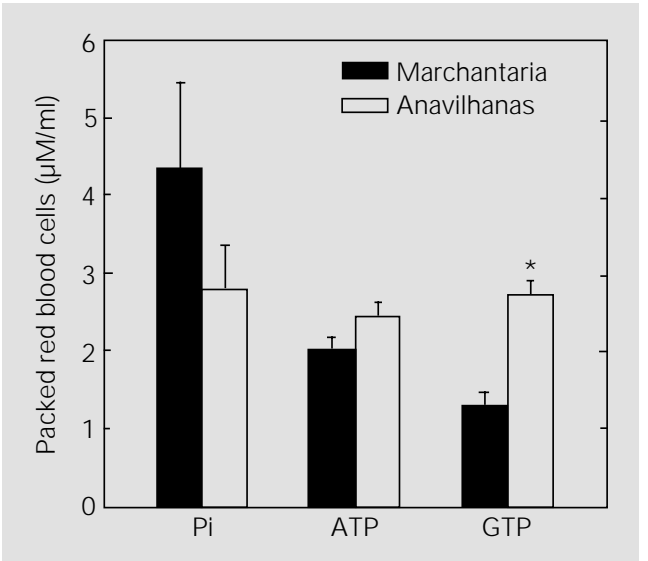

among these species, i.e., each species displays its own pattern, but intraspecific variations are not observed. The findings for $\mathrm{ADH}$ and $\mathrm{MDH}$ were similar.

MDH isozymes displayed a clear difference in tissue specificity. Isozyme $A_{2}$ was predominant in liver and $\mathrm{B}_{2}$ in white muscle, also reported for other fish species. De Luca and co-workers (33), for example, described a distribution pattern for Astyanax fasciatus that was bi-directionally divergent for s$\mathrm{MDH}$. The physiological significance of the distribution of MDH isozymes in the different tissues is not yet clear.

For PGI, the PGI-A locus was considered monomorphic even though the variant allele $\mathrm{A}_{120}$ was present at very low frequency $(<0.05)$. According to Richardson and co- workers (2), it is not common to employ a heterogeneity index if the rare allele frequency is less than 0.2. These rare alleles are maintained in populations by a balance between mutation and selection (34); in other words, the selection coefficient is the same as the mutation coefficient.

Based on the analysis of PGI-B, a single variant, one may suggest that individuals collected from Marchantaria Island and the Anavilhanas Archipelago probably belong to the same population unit $\left(\mathrm{X}_{\text {heterog }}=0.632\right.$; $\mathrm{P}>0.05)$. However, these results do not necessarily mean that there is only one population. It is difficult to state that the two samples really belong to one population, because only a low proportion of loci are being evaluated and according to King and co-workers (35), only differences (not similarities) between populations can be suggested based on electrophoretic analysis of the enzymes. Thus, the frequency values cannot be considered to be positive evidence of genetic flow between the populations analyzed.

Riggs (36) pointed out that hemoglobin components with different functional properties and/or with different relative concentrations could serve different physiological needs in variable environments. Such changes in the relative concentration of the hemoglobin bands can be considered a response to environmental variability (37). The present study shows significant differences in the mean concentration of hemoglobin bands in C. macropterus, which may be related to the condition of each environment where the animals were collected.

The majority of Amazon fishes have ATP and GTP in their red blood cells and the concentration of these phosphates varies according to the natural oscillations of oxygen availability (38). In C. macropterus, the ATP/ GTP ratio was less than 1.0 for the individuals captured at Anavilhanas Archipelago and greater than 1.0 for the samples from Marchantaria Island, showing that these animals exhibit different physiological responses to 
the predominant conditions of each environment. This capacity to adjust intraerythrocytic concentrations of organic phosphates, as well as the differences found in hemoglobin bands lead us to suggest that fish of this species may be responding to environmental specificity ( $\mathrm{pH}$, dissolved oxygen, temperature, etc). Moreover, this capacity not only allows the animals to exploit those habitats but also to remain there. Population plasticity, which is a consequence of physiological flexibility at the individual level, not only permits the exploitation of different environments, but also provides the ability to adapt to fluctuations within each environment.

The fact that $C$. macropterus is a migratory fish can explain the genetic similarity between the samples obtained from the two sites. The physicochemical characteristics of the water do not provide a barrier to prevent genetic free-flow among individuals of this species. Thus, the presence of $C$. macropterus in the two different environments can be attributed to physiological plasticity and suggests that this fish species can disperse in large areas.

The effective management of a species depends upon knowledge of their adaptive limitations (39). This present study is a first attempt to examine differences and similarities in one species of fish found in two differing environments to probe its adaptive capability. However, further studies are needed to describe the relationship between these physiological changes and environmental $\mathrm{O}_{2}$ availability, $\mathrm{pH}$, temperature, nutrition, activity, etc. Such studies are necessary to elucidate how the distribution of fish populations takes place, how fish abundance is regulated, and the limitations for each species in different habitats. This information will provide a basis for adequately managing fishing resources.

\section{References}

1. Bertollo LA, Moreira Fo $O \&$ Galetti J r PM (1986). Cytogenetics and taxonomy: considerations based on chromosome studies of freshwater fish. J ournal of Fish Biology, 28: 153-159.

2. Richardson BJ , Baverstock PR \& Adams M (1986). Allozyme Electrophoresis. A Handbook for Animal Systematics and Population Studies. Academic Press, London.

3. J amieson A \& Birley AJ (1989). The demography of a hemoglobin polymorphism in the Atlantic cod, Gadus morhua L. J ournal of Fish Biology, 35: 193-204.

4. Moran P, Penedas AM, Garcia-Vasquez E \& Linde AR (1989). Chromosomal and morphological analysis of two populations of Salmo trutta ssp fario employed in repopulation. J ournal of Fish Biology, 35: 839-843.

5. Smith PJ , Birley AJ \& J amieson A (1989). Electrophoretic studies and the stock concept in marine fishes. J ournal of Fish Biology, 35: 345-346.

6. Shaklee J B, Busack C, Marshall A, Miller $M \&$ Phelps SR (1990). The electrophoret- ic analysis of mixed-stock fisheries of salmon. In: Ratazzi GC, Scandalios J G \& Whitt GS (Editors), Isozymes: Structure, Function and Use in Biology and Medicine. Wiley-Liss Inc., New York, 235-265.

7. Weber RE (1996). Hemoglobin adaptations in Amazonian and temperate fish with special reference to hypoxia, allosteric effectors and functional heterogeneity. In: Val AL, Almeida-Val VMF \& Randall DJ (Editors), Physiology and Biochemistry of the Fishes of the Amazon. INPA, Manaus, 75-90.

8. Bertollo LAC, Takahashi CS \& Moreira Fo O (1978). Cytotaxonomic considerations on Hoplias lacerdae (Pisces, Erythrinidae). Revista Brasileira de Genética, 7: 103-120.

9. Howell WM \& Black DA (1980). Controlled silver-staining of nucleolus organizer regions with a protective colloidal developer: a 1-step method. Experientia, 36: 1014-1015.

10. Levan A, Fredga K \& Sandburg AA (1964). Nomenclature for centromeric position on chromosomes. Hereditas, 52: 201-220.

11. Val AL, Schwantes AR, Schwantes MLB
\& De Luca PH (1981). Amido hidrolisado de milho como suporte eletroforético. Ciência e Cultura, 33: 992-996.

12. Boyer SM, Fainer DC \& J ason-William ES (1963). Lactate dehydrogenase variant from human blood. Evidence for molecular subunits. Science, 141: 642-643.

13. Whitt GS (1970). Developmental genetics of the lactate dehydrogenase isozymes of fish. J ournal of Experimental Zoology, 175: 1-36.

14. Shaklee J B, Kepes KL \& Whitt GS (1973). Specialized lactate dehydrogenase isozymes: the molecular and genetic basis for the unique eye and liver LDHs of teleost fishes. Journal of Experimental Zoology, 185: 217-240.

15. Shaw CR \& Prassad R (1970). Starch gel electrophoresis of enzymes. A compilation of recipes. Biochemical Genetics, 4: 279-320.

16. DeLorenzo RJ \& Ruddle FH (1969). Genetic control of two electrophoretic variants of glucose phosphate isomerase in the mouse (Mus musculus). Biochemical Genetics, 3: 151-162. 
17. Brewer G (1970). An Introduction to Isozyme Techniques. Academic Press, New York.

18. Sokal RR \& Rohlf FJ (1981). Biometry. The Principles and Practice of Statistics in Biological Research. 2nd edn. Freeman Company, San Francisco.

19. Workman PL \& Niswander JD (1970). Population studies on south western Indian tribes. II. Local genetic differentiation in the Papago. American J ournal of Human Genetics, 22: 24-49.

20. Smithies O (1955). Zone electrophoresis in starch gel: group variation in the serum proteins of normal human adults. Biochemical J ournal, 61: 629-641.

21. Araújo JT, Toledo Filho SA \& Merino MMSS (1970). Aplicação de eletroforese em gel de amido-agar para a identificação de hemoglobinas humanas. Revista Brasileira de Pesquisas Médicas e Biológicas, 1/2: 67-69.

22. Machado PEA (1973). Estudos de hemoglobina $A_{1}, A_{2}$ e $S$ em siclêmicos e não siclêmicos. Doctoral thesis, Faculdade de Ciências Médicas e Biológicas de Botucatu, São Paulo.

23. Bartlett GR (1959). Phosphorus assay in column chromatography. J ournal of Biological Chemistry, 254: 466-468.

24. Bartlett GR (1982). Phosphates in red cells of a hagfish and a lamprey. Comparative Biochemistry and Physiology, 73A: 141145.

25. Hochberg VBM \& Erdtmann B (1988). Cytogenetical and morphological considerations on Rhamdia quelen (Pisces, Pimelodidae). The occurrence of B chro- mosomes and polymorphic NOR regions. Revista Brasileira de Genética, 11: 563576.

26. Fenocchio AS \& Bertollo LAC (1990). Supernumerary chromosome in a Rhamdia hilarii population (Pisces, Pimelodidae). Genetica, 81: 193-198.

27. Dias AL \& Foresti F (1993). Cytogenetic studies on fishes of the family Pimelodidae (Siluroidei). Revista Brasileira de Genética, 16: 585-600.

28. Martins-Santos IC, J ulio-J r HF \& Burin I (1996). Karyotypic studies of four species of the Sorubiminae subfamily (Pisces, Siluriformes). Caryologia, 49: 73-80.

29. Fenocchio AS \& Bertollo LAC (1992). Karyotype similarities among Pimelodidae (Pisces, Siluriformes) from the Brazilian Amazon region. Cytobios, 69: 41-46.

30. D'Avila-Limeira NC, Almeida-Val VMF \& Schwantes MLB (1991). Lactate dehydrogenase (LDH) in 27 species of Amazon fish: Adaptive and evolutive aspects. Comparative Biochemistry and Physiology, 100B: 391-398.

31. Panepucci LL, Schwantes ML \& Schwantes AR (1984). Loci that encode the lactate dehydrogenase in 23 species of fish belonging to the orders Cypriniformes, Siluriformes \& Perciformes: Adaptative features. Comparative Biochemistry and Physiology, 77B: 867-876.

32. Basaglia $F$ (1989). The isozymes of lactate dehydrogenase, malate dehydrogenase and glucophosphate isomerase in Italian ictalurids. Comparative Biochemistry and Physiology, 92B: 395-398.

33. De Luca PH, Schwantes MLB \&
Schwantes AR (1983). Adaptative features of ectothermic enzymes. IV. Studies on malate dehydrogenase of Astyanax fasciatus (Characidae) from Lobo Reservoir (SP, Brasil). Comparative Biochemistry and Physiology, 47B: 315-324.

34. Ohta T (1976). Role of very slightly deleterious mutations in molecular evolution and polymorphism. Theoretical Population Biology, 10: 254-275.

35. King DPF, Fergson A \& M offett IJ J (1987) Aspects of the population genetics of herring Clupea harengus around the British Isles and in the Baltic Sea. Fisheries Research, 6: 35-52.

36. Riggs A (1979). Studies of the hemoglobins of Amazonian fishes: an overview. Comparative Biochemistry and Physiology, 62A: 257-272

37. Val AL, Schwantes AR, Almeida-Val VMF \& Schwantes MLB (1985). Hemoglobin, hematology, intraerythrocytic phosphates and whole blood Bohr effect from lotic and lentic Hypostomus regani populations (São Paulo, Brazil). Comparative Biochemistry and Physiology, 80B: 737-741.

38. Val AL (1993). Adaptation of fishes to extreme conditions in fresh waters. In: Bicudo J E (Editor), Vertebrate Gas Transport Cascade: Adaptations to Environment and Mode of Life. CRC Press, Boca Raton, 43-53.

39. Warren CE \& Liss W (1980). Adaptation to aquatic environments. In: Lacky RT \& Nielsen LA (Editors), Fishery Management. Blackwell Scientific Publications, London, 15-40. 